\title{
Ventricular Aneurysm
}

\author{
V I K I N G O L O V B J Ö R K \\ From the Department of Thoracic Surgery, University Hospital, Uppsala, Sweden
}

A cardiac aneurysm represents a diseased and weakened cardiac wall, which will balloon out during systole. Approximately $85 \%$ of such aneurysms are caused by coronary occlusion. Cardiac aneurysms usually involve the left ventricle; those of the right ventricle are rare. Most of these aneurysms develop during the period of myocardial necrosis and softening, especially during the first few weeks after coronary occlusion. Experimental evidence supports the belief that the development of a ventricular aneurysm is favoured by allowing a patient to be up and walking around too soon, which means within a week or two after an acute infarction. A ventricular aneurysm may follow necrosis of the myocardium caused by rheumatic fever and may also be caused by infective endocarditis with abscess of the myocardium, particularly in association with mycotic coronary arteritis, congenital defects, and trauma. Spontaneous rupture of a cardiac aneurysm is rare. If it does occur, it is most likely to occur during the first 10 days after the onset of an infarction. The usual terminal event is cardiac failure or embolization.

John Hunter (1757) first described a ventricular aneurysm. Schlichter, Hellerstein, and Katz (1954) stated that the prognosis was half as favourable in a patient developing an aneurysm after myocardial infarction as in others. In a series of patients with cardiac aneurysm, $73 \%$ died within three years and $88 \%$ died within five years. The cause of death in $70 \%$ was congestive heart failure. The presence of a non-contractile sac on the anterior surface of the left ventricle impairs the normal contractile force of the left ventricle and thus significantly reduces cardiac output.

The first attempt to operate on a left ventricular aneurysm was made by Beck (1944). Gordon Murray reported three years later upon the experimental excision of myocardial infarcts and showed that the cardiac output could be increased by removing the expansion chamber. Bailey, Bolton, Nichols, and Gilman (1958) reported the excision of ventricular aneurysms using a special clamp at a closed operation. Cooley, Collins,
Morris, and Chapman (1958) reported the first successful open operation for a massive left ven- 6 tricular aneurysm; they used a pump oxygenator for temporary cardiopulmonary by-pass.

The purpose of this paper is to report seven cases of ventricular aneurysm treated at the Thoracic Surgical Clinic of the University of $z$ Uppsala ; five were acquired left ventricular aneurysm, one was a congenital left ventricular $\stackrel{\mathcal{S}}{\mathcal{}}$ aneurysm, and one was a right ventricular $\vec{\bullet}$ aneurysm.

\section{MATERIAL}

The cases are summarized in the Table. There was one small left ventricular aneurysm combined with $\frac{0}{D}$ a mitral stenosis, and one large right ventricular aneurysm combined with a large $5 \times 4 \mathrm{~cm}$. $\vec{\partial}$ secundum atrial septal defect and a 20 -litres shunt from the left to the right atrium in a huge heart of $910 \mathrm{ml} . / \mathrm{m} .^{2}$ body surface area and a right ventricular pressure of $45 \mathrm{~mm}$. $\mathrm{Hg}$.

Four aneurysms had developed following infarction. In two the aneurysm included the apex of the $x$ left ventricle with significant paradoxical move- $\frac{0}{3}$ ments (case 3 (Fig. 1) and case 4 (Fig. 2) ). In case 5 the aneurysm included a $5 \times 5 \mathrm{~cm}$. large fibrotic $O$ area on the anterior part of the left ventricle with no movements. The patient had undergone $\mathrm{a}$ 을 coronary thrombendarterectomy of the left $D$ descending artery without obtaining a good retrograde flow and without improvement and was in N failure. The oldest patient (case 6) was 60 years of age; he had a similar high anterior left ventricular 0 aneurysm but with calcification in the wall preventing movements. There were scattered, large, white scars in the myocardium (Fig. 3).

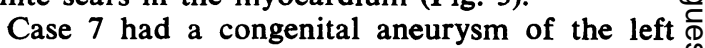
ventricular apex, separated by a fibrotic membrane $\stackrel{?}{+}$ from the left ventricular chamber. The communi- $\square$ cation was so small that the contrast medium used $\stackrel{+}{+}$ to fill the left ventricle did not pass into the $\stackrel{\Phi}{\Phi}$ aneurysm, although the cavity was as big as an $\stackrel{\mathbb{Q}}{\square}$ orange, nor could an opening from the aneurysm into the ventricle be found at open operation, 
TABLE

FINDINGS IN SEVEN PATIENTS WITH LEFT VENTRICULAR ANEURYSM

\begin{tabular}{|c|c|c|c|c|c|c|c|c|c|c|c|}
\hline Age & Sex & Diagnosis & $\begin{array}{c}\text { Diagnosis } \\
\text { Confirmed by }\end{array}$ & $\mid \begin{array}{c}\text { Heart } \\
\text { Size } \\
\left(\mathrm{ml} . \mathbf{m} .^{2}\right)\end{array}$ & $\begin{array}{l}\text { Size of } \\
\text { Aneu- } \\
\text { rysm } \\
\text { (cm.) }\end{array}$ & Surgery & $\begin{array}{l}\text { Perfu- } \\
\text { sion } \\
\text { (min.) }\end{array}$ & $\begin{array}{l}\text { Aortic } \\
\text { Occlu- } \\
\text { sion } \\
\text { (min.) }\end{array}$ & $\begin{array}{l}\text { Respi- } \\
\text { rator } \\
\text { Treat- } \\
\text { ment }\end{array}$ & $\begin{array}{c}\text { Obser- } \\
\text { vation } \\
\text { (yr.) }\end{array}$ & Results \\
\hline 48 & $\mathbf{F}$ & $\begin{array}{l}\text { Mitral stenosis } \\
\text { + left ventricular } \\
\text { aneurysm }\end{array}$ & Operation & 840 & $2 \times 2$ & $\begin{array}{l}\text { Commissuro- } \\
\text { tomy + obli- } \\
\text { teration by } \\
\text { mattress } \\
\text { sutures over } \\
\text { pericardial } \\
\text { strips }\end{array}$ & 0 & 0 & 0 & 5 & Alive and well \\
\hline 39 & $\mathbf{F}$ & $\begin{array}{l}\text { Atrial septal } \\
\text { defect }+ \text { right } \\
\text { ventricular } \\
\text { aneurysm }\end{array}$ & Operation & 910 & $4 \times 4$ & $\begin{array}{l}\text { Closure of } \\
\text { A.S.D. + } \\
\text { patch rein- } \\
\text { forcement of } \\
\text { aneurysm + } \\
\text { pacemaker } \\
\text { Hypothermia }\end{array}$ & 0 & & + & 2 & $\begin{array}{l}\text { Alive and well } \\
\text { Heart now } \\
590 \mathrm{ml} . \text { 'm.2 }\end{array}$ \\
\hline 58 & $\mathbf{M}$ & $\begin{array}{l}\text { Post-infarction } \\
\text { left ventricular } \\
\text { aneurysm }\end{array}$ & $\begin{array}{l}\text { Angiocardio- } \\
\text { graphy from } \\
\text { pulmonary }\end{array}$ & 620 & $5 \times 5$ & Excision & 52 & $3 \frac{1}{2}$ & + & 2 & $\begin{array}{l}\text { Recurrence; } \\
\text { died after } \\
\text { reoperetion }\end{array}$ \\
\hline 52 & $\mathbf{M}$ & $\begin{array}{l}\text { Post-infarction } \\
\text { left ventricular } \\
\text { aneurysm }\end{array}$ & Operation & 650 & $5 \times 5$ & Excision & 53 & 16 & + & 3 & Alive and well \\
\hline 52 & $\mathbf{M}$ & $\begin{array}{l}\text { aneurysm } \\
\text { Post-infarction } \\
\text { left ventricular } \\
\text { aneurysm }\end{array}$ & $\begin{array}{l}\text { Angiocardio- } \\
\text { graphy from } \\
\text { pulmonary }\end{array}$ & 490 & $5 \times 5$ & Excision & 57 & $\frac{1}{2}$ & + & 1 & Alive \\
\hline 60 & $\mathbf{M}$ & $\begin{array}{l}\text { Post-infarction } \\
\text { calcified left } \\
\text { ventricular } \\
\text { aneurysm }\end{array}$ & $\begin{array}{l}\text { Angiocardio- } \\
\text { graphy from } \\
\text { left atrium } \\
\text { (transseptal) }\end{array}$ & 600 & $5 \times 5$ & Excision & 61 & 3 & + & 0 & $\begin{array}{l}\text { Died } 5 \text { days } \\
\text { after operation }\end{array}$ \\
\hline 22 & $\mathbf{M}$ & $\begin{array}{l}\text { Congenital left } \\
\text { ventricular } \\
\text { aneurysm }\end{array}$ & $\begin{array}{l}\text { Angiocardio- } \\
\text { graphy }\end{array}$ & 490 & $5 \times 6$ & Excision & 65 & $2 \frac{1}{2}$ & + & 2 & Alive and well \\
\hline
\end{tabular}

although the aneurysm was filled with blood without thrombosis.

\section{DIAGNOSIS}

The diagnosis was unexpected and made at operation in the patient who had aneurysm com-

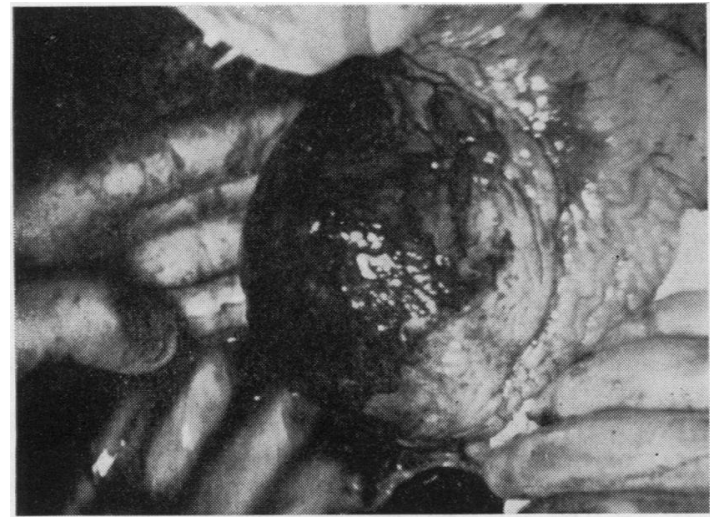

FIG. 1

FIG. 1. Case 3. A huge apical left ventricular aneurysm with paradoxical movement in a 58-year-old man.

FIG. 2. Case 4. A huge left ventricular apical aneurysm with significant paradoxical systolic expansions in a 52-year-old man. bined with mitral stenosis and in the patient with atrial septal defect as well as in one patient who underwent surgery for angina pectoris. In four patients the diagnosis was made before operation and confirmed by pulmonary artery angiography ; paradoxical or no left ventricular wall movement

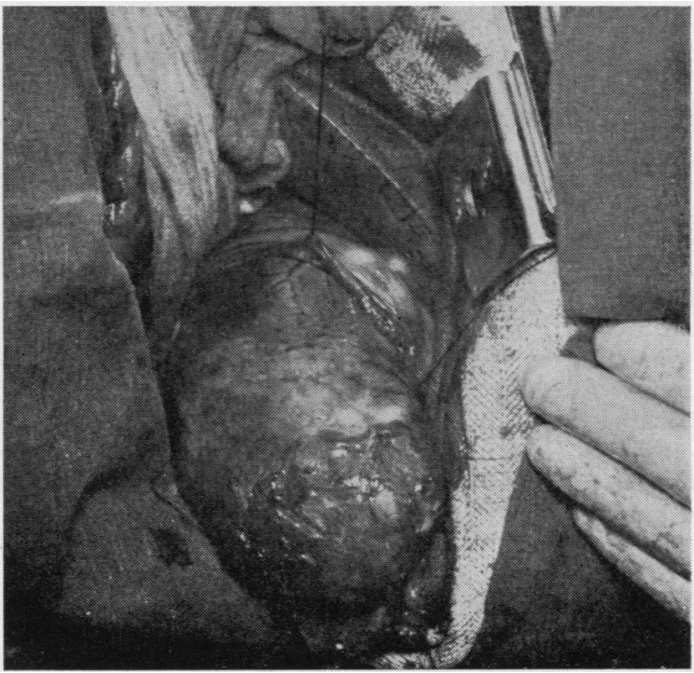

FIG. 2 


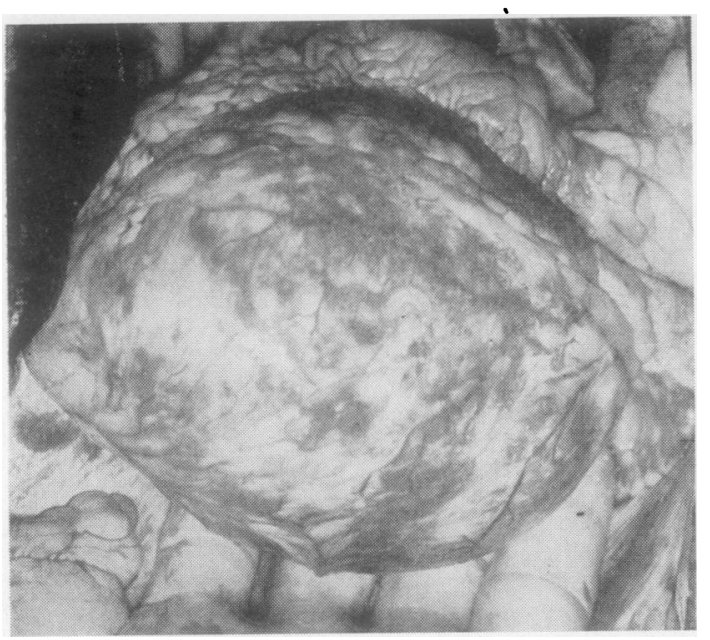

FIG. 3. Case 6. The wall of the anterior left ventricular aneurysm shows calcification, and numerous large white scars can be seen scattered around the left ventricle and on its posterior surface in a 60-year-old man.

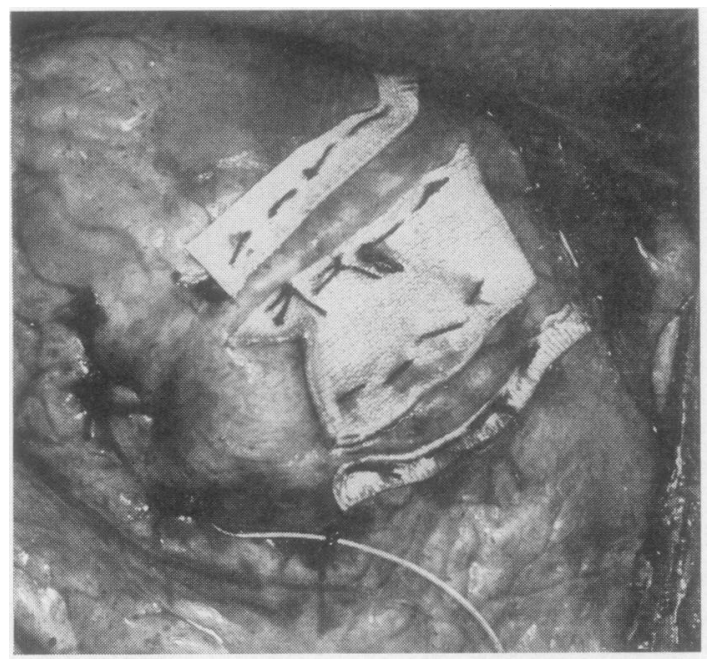

FIG. 4. Case 2. A huge thin-walled anterior right ventricular localized aneurysm in a 39-year-old woman with a heart of $910 \mathrm{ml} . / \mathrm{m.}^{2}$ was treated by a patch reinforcement with mattress sutures over strips of teflon. The paradoxical movements were controlled by this patch reinforcement. Wires were applied to the myocardium for an external pacemaker as a total block developed. Closure of the secundum defect was performed by continuous and isolated mattress sutures under inflow occlusion during hypothermia at $30^{\circ} \mathrm{C}$. After a year the heart size has diminished to $590 \mathrm{ml} . / \mathrm{m.}^{2}$; spontaneous rhythm is between 50 and 60 beats per minute, increasing to 80-90 during a work load test. The pacemaker is still used as it is hoped the block will disappear when the heart size is diminished. was observed as well as no trabeculation on the inside of the left ventricular wall when the $\bar{\sigma}$ aneurysm was filled with thrombotic material.

\section{SURGICAL TECHNIQUE}

The smallest aneurysm was treated by mattress sutures over strips of pericardium which controlled the paradoxical movements.

The right ventricular aneurysm was treated by a patch reinforcement as the thin dilated adjacent $\overrightarrow{\hat{\vec{\gamma}}}$ right ventricular wall would not hold sutures safely after an excision. The paradoxical movements were controlled by this patch reinforcement (see Fig. 4).

The large acquired and congenital left ventricu- 은 lar aneurysms were excised at open operation using a heart-lung machine to prevent embolism 3 and improve the haemodynamics. A bilateral subcostal incision entering the left fifth and the right $\stackrel{\odot}{\supset}$ fourth intercostal spaces with transverse section of $\overrightarrow{0}$ the sternum was used. The perfusion time was about one hour, and the aorta was occluded for only a short time at the beginning of perfusion, when the aneurysm was opened, to prevent embolism.

After the aneurysm had been opened, all the $\frac{\text { ڤे }}{8}$ thrombotic material was evacuated, then the aneurysm was excised, care being taken not to $\overrightarrow{\overrightarrow{0}}$ take so much of the left ventricular wall as to 3 make the left ventricle too small. The papillary muscles were inspected and avoided. It was found advisable to leave the last centimetre of fibrotic tissue at the periphery of the aneurysm as this $\frac{0}{d}$ tissue seemed to hold sutures better than the myo- $\times$ cardium itself (see Fig. 5). Mattress and over- $\frac{0}{3}$ and-over isolated sutures were applied over strips of tefion to reinforce the suture lines. (See Fig. 6.)윽

As the ventriculotomy was closed the left ventricle was allowed to fill with blood, and there was no problem with air embolism in these cases. The pericardium was closed over the suture line but left open at the base of the heart. Six patients $N$ needed post-operative respirator treatment.

\section{RESULTS}

The results are summarized in the Table. One 60-0 year-old patient (case 6) died five days after $\bar{\complement}$ operation. He had a calcified wall of the aneurysm $\stackrel{+}{+}$ which prevented paradoxical movements. We considered that this large patch of calcium, which $\frac{}{\Phi}$ made most of the anterior part of the left ventricle immobile, impaired the ventricular work enough to warrant excision. Experience from case 5, where a huge fibrotic immobile left anterior ventricularo 


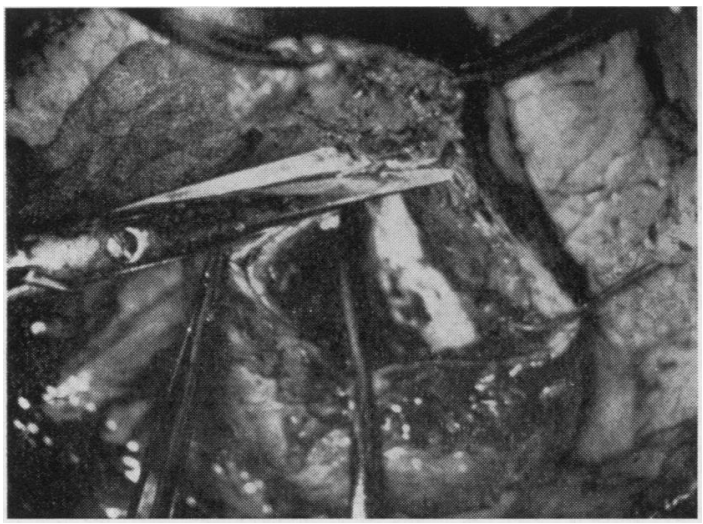

FIG. 5

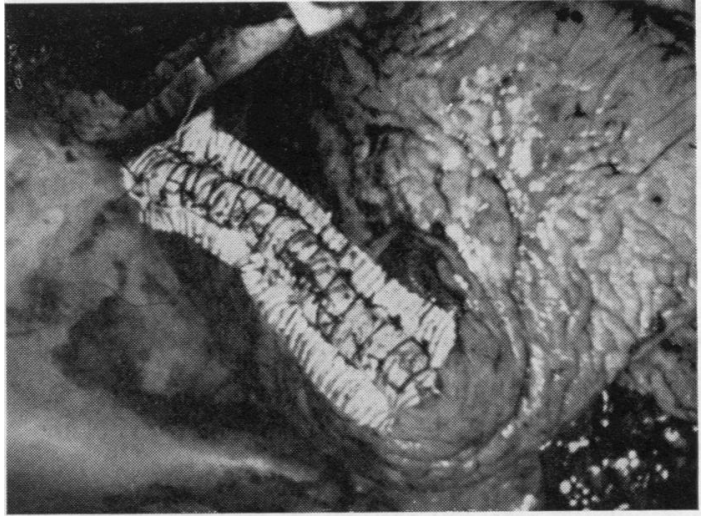

FIG. 6

FIG. 5. Case 3. The aneurysm is excised, leaving a $1 \mathrm{~cm}$. rim of fibrotic tissue. FIG. 6. Case 3. Closure is effected by one row of mattress sutures and one row of over-and-over sutures applied over strips of teflon.

wall had been excised, led us to anticipate some improvement in a severely ill patient in failure. In case 6 , however, the remaining part of the left ventricle was also severely changed by scattered, numerous, white, fibrotic scars. Too little improvement could therefore be gained from the operation, and death occurred.

One 58-year-old man was much improved for one and a half years. Then during anticoagulation treatment a false aneurysm with communication to the left ventricle through the suture line occurred. $\mathrm{He}$ died after reoperation.

The best results were obtained in patients with aneurysm having paradoxical movements. Careful study by angiocardiography from the left atrium (transseptally) or from the pulmonary artery in order to determine the degree of systolic expansion of the aneurysm and the contractility of the remaining part of the left ventricle is essential before excision is contemplated.

In conclusion four patients were significantly improved, one was not improved, and two died.

\section{DISCUSSION}

In patients with ventricular aneurysm the stroke volume of the left ventricle at rest is reduced because the force of contraction of the remaining myocardium is dissipated in the flaccid sac. This is most evident during exercise. The good result reported by Cooley et al. and found in our series has made us accept excision of ventricular aneurysm as the correct method of treatment in selected cases.

\section{SUMMARY}

Seven cases of ventricular aneurysm are reported : one small left ventricular aneurysm was treated by mattress sutures; one right ventricular aneurysm was reinforced by a patch ; five large left ventricular aneurysms, one of them congenital and four following infarction, were excised at open operation using the heart-lung machine. Two patients in this group died and four were improved.

\section{REFERENCES}

Bailey, C. P., Bolton, H. E., Nichols, H., and Gilman, R. A. (1958) Ventriculoplasty for cardiac aneurysm. J. thorac. Surg., 35, 37. Beck, C. S. (1944). Operation for aneurysm of the heart. Ann. Surg., $120,34$.

Cooley, D. A., Collins, H. A., Morris, G. C., and Chapman, D. W. (1958). Ventricular aneurysm after myocardial infarction. Surgical excision with use of temporary cardiopulmonary bypass. J. Amer. med. Ass., 167, 557 . J. Amer. med. Ass., 167, 557. H., and Chapman, D. W. (1959). Henly, W. S., Amad, K. H., and Chapman, D. W. (1959). of surgical treatment. Ann. Surg., 15 J, 595.

Hunter, J. (1757). An account of the dissection of morbid bodies. Original manuscript in the library of the Royal College of Surgeons. No. 32, p. 30 .

Murray, G. (1947) The pathophysiology of the cause of death from coronary thrombosis. Ann. Surg., $123,523$.

Schlichter, J., Hellerstein, H. K., and Katz, L. N. (1954). Aneurysm of the heart : a correlative study of 102 proved cases. Medicine, Baltimore, 33, 43. 